\title{
Continuities in the Soviet Period
}

Link to publication record in Manchester Research Explorer

\section{Citation for published version (APA):}

Tihanov, G., Leatherbarrow, W. (Ed.), \& Offord, D. (Ed.) (2010). Continuities in the Soviet Period. In A History of Russian Thought (pp. 311-339). Cambridge University Press.

\section{Published in:}

A History of Russian Thought

\section{Citing this paper}

Please note that where the full-text provided on Manchester Research Explorer is the Author Accepted Manuscript or Proof version this may differ from the final Published version. If citing, it is advised that you check and use the publisher's definitive version.

\section{General rights}

Copyright and moral rights for the publications made accessible in the Research Explorer are retained by the authors and/or other copyright owners and it is a condition of accessing publications that users recognise and abide by the legal requirements associated with these rights.

\section{Takedown policy}

If you believe that this document breaches copyright please refer to the University of Manchester's Takedown Procedures [http://man.ac.uk/04Y6Bo] or contact uml.scholarlycommunications@manchester.ac.uk providing relevant details, so we can investigate your claim.

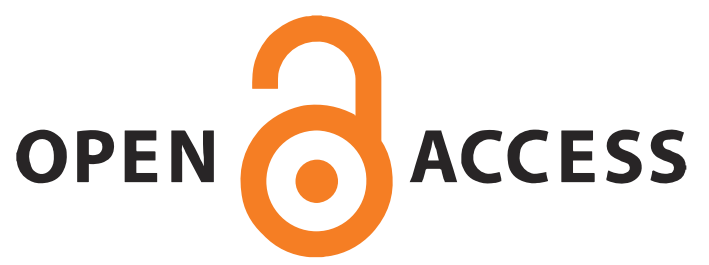




\title{
Continuities in the Soviet period
}

\author{
Galin Tihanov
}

Intellectual history presents a bundle of continuities and discontinuities enacted, sometimes simultaneously, within cultures that evolve over time. In this essay I focus on the continuities that permeate - often hidden behind dramatic political changes - the scene of philosophy and social thought in the Soviet period, from the October Revolution in 1917 to the demise of the USSR in 1991. Limitations of space mean that difficult decisions have had to be made as to what ought to be included and what could be left out. Since the dominant intellectual paradigm of the period was Marxism, it was beyond doubt that any serious engagement with the question of continuity must not simply address Marxism but should actually put it right at the centre of attention. Ignoring Marxism and preferring instead to explore solely various non-Marxist discourses would have resulted in a failure to grasp the crucial place of Marxism in the often subterraneous dynamics of stability and change which sustained and shot through the public discourses of philosophy and the social sciences in the Soviet period. With reference to Marxism, the continuity inscribed in this dialectic of permanence and transformation had two important aspects: the self-awareness and positioning of Soviet Marxism vis-à-vis western non-Marxist philosophy, and through this, but also independently of it, vis-à-vis pre-I9I7 Russian thought.

The second part of the essay examines various discourses of exceptionalism, concentrating on the revival of Slavophilism, pochvennichestvo (a current of thought that crystallised in the i86os and displayed some affinities with Slavophilism but was more unambiguously conservative and at times also anti-Semitic) and Eurasianism. The emphasis here is deliberately on developments in the Soviet Union. I have elected not to include a separate overview of émigré currents of thought, because this would have reproduced the wrong notion of Russian émigré intellectuals as being the only heirs to the pre-19I7 tradition, thus also reinforcing the long-maintained - and rather misleading - picture of a constant and unbridgeable chasm between Soviet and émigré intellectual life. The diaspora and the mainland were involved in 
a historically changing dynamic of impact, with Soviet culture and thought being more influential among the diaspora before the Second World War, followed, especially since the I96os, by an extended period in which émigré thought (both of pre- and post-Second World War provenance) was increasingly consequential for the Soviet debates. The detailed identification of the impact of Soviet intellectual developments on the various émigré currents of thought, as well as the thorough examination of the relevance of the latter for Soviet intellectual life, are all tasks for the future (a comprehensive study, to take just one important example, of the reception of Soviet Marxism in the Russian diaspora before 1945 is yet to be written). Here I can only begin to set the overall agenda, sketching very briefly the (dis)continuities revealed in the revival of Eurasianism in the Soviet Union. (Other instructive cases, well researched by now, concern the overlaps and exchanges between émigré thinkers and intellectuals living in the Soviet Union involved in the appropriation - in Harbin, Prague, Paris, Moscow, Kaluga, Petrograd and Minsk (to name only a few of the locations) - of Fedorov's ideas, as well as the impact of Berdiaev's émigré works, particularly his New Middle Ages, in the I96os when, together with Djilas's The New Class, they became an inspiration for the opposition group VSKhSON (the AllRussian Social-Christian Union for the Liberation of the People), established in Leningrad in 1964. $)^{\mathrm{I}}$

Finally, for the purposes of this chapter I have decided to focus on the continuities with pre-I9I7 Russian thought. This qualification is not trivial. The seven decades of Soviet history were long enough for continuities to begin to develop between focal points of thought elaborated after the October Revolution. But this process was hampered by various factors and, on the whole, began to come to prominence only at the very end of the Soviet period, around 1990, reaching fruition in the years afterwards. Thus throughout the formative stages of the Tartu-Moscow School of semiotics and cultural theory neither Shpet (who in the 1920s published important work foreshadowing various tenets of structuralism and semiotics), nor Losev (one of the first philosophers in the Soviet Union to ponder concepts such as 'sign' and 'structure') were actively appropriated by Lotman and his colleagues. Losev even complained in 1968 that he was not being cited in their works. ${ }^{2}$ Only Florensky seemed to have been received and appropriated more intensely by the Tartu-Moscow School. Contrast this largely broken line of continuity in the 1960s with the impact of Bakhtin towards the end of the I980s. Not only did he leave a visible trace in a string of more specialised historical and literary studies in the I970s and I980s by pre-eminent intellectuals such as Likhachev, Averintsev and 
Gurevich, but by 1991, the year of the collapse of the Soviet Union, his theory of dialogism had become the cornerstone of Bibler's doctrine of 'dialogue of cultures', which assisted Bibler and his associates in developing new school curricula and a new philosophy of education. ${ }^{3}$ Thus, while in the epilogue I add one more significant example of Soviet philosophy of history and culture engaging with earlier Soviet thought, the exposition remains largely concerned with continuities that form a bridge to pre-revolutionary intellectual developments.

\section{CONTINUITIES WITHIN SOVIET MARXISM}

The political rupture of 1917 and the ensuing consolidation of Marxism as a ruling ideology have long served to obscure several important points of continuity with the past. To begin with, until 1930, when Losev's The Dialectics of Myth was published in Moscow (containing a qualification of dialectical materialism as an 'outright absurdity'), ${ }^{4}$ philosophising in a nonMarxist key and publicising the results of such activity continued to be a legitimate business. Second, the backbone of philosophical education continued to include, well into the I940s, both pre-revolutionary textbooks and the works of a significant number of non-Marxist philosophers (many of them - but not all - drawn into the orbit of materialism and dialectics like their predecessors). At the end of the 1920 even at the leading Institute of Red Professors the old pre-I9I7 textbooks on the history of philosophy were still being widely used; ${ }^{5}$ when logic was restored to the curriculum in 1946 , the use of a pre-revolutionary textbook by Chelpanov was permitted. ${ }^{6}$ According to figures supplied by Mitin, one of Stalin's most powerful official philosophers, in the period I897-1916 Aristotle's works were published in a total of 1,000 copies, Hegel's in 4,500 copies and Spinoza's in 7,700 copies. In 1917-38 these figures rose, respectively, to 78,300, 200,500 and 55,200. ${ }^{7}$ As late as 1936 the required reading for the postgraduate oral examinations in philosophy at the Institute of History, Philosophy and Literature included - along with Marx, Lenin and Stalin - Kant, Hegel, Aristotle, Bacon, Hobbes, Locke, Descartes, Spinoza, Leibniz and Hume. ${ }^{8}$ The only demonstrable weakness of the philosophy curriculum, apart from the rigidly controlled ideological interpretation, was the neglect of twentieth-century western philosophy. Even after the list of canonical western names was extended further, following suggestions for a curriculum reform in 1938, it still stopped with Nietzsche (whose year of death - 1900 appropriately indicated the disregard for twentieth-century non-Marxist philosophy). ${ }^{\text {? }}$ 
But most importantly, well into the 1920s Soviet Marxism still bore the birthmarks of a tradition of thought originating at the crossroads of Russian 'Legal Marxism', 'Christian socialism' and various attempts to reconcile Marxism with neo-Kantianism and the philosophy of Mach. Three of the most illustrious representatives of Russian religious thought in the twentieth century - Berdiaev, Sergey Bulgakov and Frank - had actually started their intellectual careers as sympathisers of Marxism and the socialist idea. Others, notably Lunacharsky and Gorky, had engaged with Marxism as part of a social platform that presented a powerful mixture of religious idealism and radical Nietzschean activism (the resulting doctrine, vestiges of which continued to be influential into the mid-I920s, is usually referred to as bogostroitel'stvo (God-building)). Others still, especially Plekhanov and Bogdanov, had anchored Marxism in a paradigm of thought that was either more broadly sociological (Plekhanov) or rooted in a more sympathetic appropriation of contemporary western philosophy (Bogdanov). While Bogdanov was never really admitted to the canon of official Soviet Marxism (he was criticised in the 1920 for wishing to dissolve Marxism into his own 'general science of organisation', the so-called tektology) ${ }^{\mathrm{IO}}$, Plekhanov, whose work fell almost entirely in the pre-1917 period, enjoyed a more uneven reputation. It reflected the waves of relaxation and ossification in official doctrine and the successive mobilisations of Marxism for the purposes of establishing Stalin's authority and advancing the agenda of nation-building. For most of the $1920 \mathrm{~s}$ Plekhanov remained an authority for all those seeking to inscribe Marxism in a materialist tradition of thought that could lay claim to a serious pedigree going back to Spinoza. (Deborin even drew a distinction between Lenin and Plekhanov, describing the latter - approvingly - as 'the theoretician', while Lenin was praised for being 'the man of action, the politician, the leader'.) ${ }^{\mathrm{II}} \mathrm{In}$ the early 1930s, however, Plekhanov fell from grace for exactly the same reason: he was chastised for considering dialectical materialism a mere strand of materialism, not essentially different from other varieties of materialism in western thought. At the same time, he became unacceptable also because of his admonition (towards the end of his life) that Soviet Russia had not had a sufficiently long capitalist evolution, and that therefore socialism had not been allowed to emerge as the result of a natural process of radicalising the contradictions of capitalism. Yet in the early I940s, amid a new wave of nationalist propaganda during the war, Plekhanov resurfaced once again as part of the canon of Russian Marxist thought. Pavel Iudin praised him in 1943 as 'the greatest and most distinguished Marxist, after Marx and Engels, of the pre-Lenin epoch', a 'great patriot' and a thinker who had enriched 'Russian national culture'. ${ }^{2}$ 
Plekhanov's consistent and, in the I920s, still influential attempt to derive Marxism, including its understanding of society and social change, from the tradition of western materialism is a helpful reminder of the larger continuities characteristic of the Soviet period. The evolution of Soviet Marxism was marked by an incessant need to deal with its presumed and actual forefathers; the work of establishing the intellectual genealogy of Marxism continued after 1917 and was the one aspect of Marxist thought in the Soviet Union that did not lose momentum even in the decades of Stalinism. Two figures of western philosophy became the main points of reference in this debate, Hegel and Spinoza, although the search for legitimate predecessors was often extended to encompass Feuerbach, as well as the major representatives of nineteenth-century German idealism. ${ }^{13}$ Both Spinoza and Hegel have been generic concerns for Marxism (as the work on Spinoza by western Marxists, notably Althusser and Balibar, and on Hegel by Lucio Coletti and Antonio Negri among others, testifies), but the Soviet debates were particularly intense. By the early I930s Russian literature on Spinoza exceeded in quantity that of any country in the West. ${ }^{\text {I4 }}$ The publication of Lunacharsky's From Spinoza to Marx (1925), which restated some of Lunacharsky's positions from the time of his bogostroitel'stvo, was part and parcel of the growing polemic about Spinoza that took place in the second half of the I920s. Coming from very different methodological perspectives, and reaching very different conclusions, Liubov Akselrod (the major philosopher of the mechanists, also known by the pseudonym 'Orthodox') and Deborin (the leader of the opposite camp, which was to become known by his name) both sought to determine the relationship between Spinoza's philosophy and Marxist materialism. Much later, Ilenkov re-engaged with Spinoza in his innovative studies of Marx. He even planned to write a book on Spinoza, but the project did not materialise. ${ }^{\mathrm{IS}}$

The persistent preoccupation with Hegel was of particular importance for Soviet Marxism, because it would put it in an initially direct (then increasingly mediated) contact with a very long tradition of Russian nonMarxist philosophical appropriations of the German philosopher, stretching from the Slavophiles to Ivan Ilin, who just a year after the October Revolution had published a two-volume study of Hegel and the 'concreteness of God and man'. Lenin, whose own Philosophical Notebooks (published posthumously in 1929) contained ample evidence of his ambition to master Hegel's methodology, is said to have liked the book so much that he decided to release Ilin from prison (which did not save him from deportation in 1922). ${ }^{16}$ 
Interest in Hegel was further motivated by the necessity to gauge the originality of the Marxist dialectical method. Deborin made the first sustained effort to do that in his book Marx and Hegel (1923), which was later criticised on the grounds that it overemphasised Hegel's role. Realising Hegel's significance for the principles and even the vocabulary of Soviet Marxism (the important concept of partiinost' was little more than a replica of Hegel's Parteilichkeit), ${ }^{17}$ a Party resolution envisaged the speedy publication of a fifteen-volume edition of his works by 1932 (not completed, in fact, until well after the Second World War) ${ }^{18}$ Hegel also figured prominently in the famous third volume of the collective History of Philosophy (1943), which gained the nickname 'the grey horse' (describing both the colour of its binding and its intellectual power). The chapter on Hegel occupied more than ninety pages (equalling the combined space allocated to the five thinkers discussed under the heading 'utopian socialism'), stressing his central position in the pre-history of Marxism and arguing for Hegelian dialectics as the 'pinnacle of all bourgeois thought' and the achievement of a 'genius thinker'. ${ }^{\text {I9 }}$ As was the case with Plekhanov's rising stock, the nationalist ideological campaign of the war years clearly affected the fate of 'the grey horse'. Although seven volumes were conceived (and the volume on Russian philosophy, number six in the series, was already in preparation), and although the authors had been awarded the Stalin Prize in 1942 for the two preceding volumes, the Party in 1944 decreed that the third volume had been a serious mistake, allegedly failing to expose the limitations of Hegel's idealist dialectics and to criticise his glorification of the Germans as a 'chosen people'. Thus the whole multi-volume project came to an end. ${ }^{20}$ Lukács, a prominent exile in Stalin's Moscow, at the end of 1942 defended a professorial dissertation on the young Hegel as an important forebear of Marxism. After the Party resolution of 1944, attempts to publish Lukács's dissertation as a book in Russian invariably failed (it was only in 1956 that a portion of Young Hegel appeared in Problems of Philosophy; the book in its entirety was not published in Russian until 1987). In 1947 Zhdanov declared at an official gathering of Soviet philosophers that the Hegel issue had been settled. ${ }^{2 I}$

Yet the need to keep alive the internal dialogue of Marxism with the traditions of western thought - and through this also, if not always directly, with pre-I9I7 Russian philosophy - was acutely felt once again during the revival of Marxist philosophy after Stalin's death. Beginning in the midI930s and through to the early I950s, the serious study of Marxism in the Soviet Union had suffered neglect. In 1935 the 'Marx, Engels, Lenin' Institute suspended publication of the German-language edition of the 
collected works of Marx and Engels, with only twelve of the planned forty volumes published. Work on the Russian-language edition continued until 1947. ${ }^{22}$ The decade from 1947 (the year that saw the public condemnation, led by Zhdanov, of G. F. Aleksandrov's History of Western Philosophy) until the mid-I950s, when the 'thaw' years began, could confidently be regarded as the direst time for philosophy in the Soviet Union. When in the early I950s a group of young philosophers at Moscow State University (MGU), including Ilenkov and the future dissident writer and sociologist Aleksandr Zinoviev, began to study the logic of Marx's Capital, both Hegel and Spinoza were revived once again. Ilenkov and his colleagues were soon stigmatised as 'gnoseologists', for they believed that philosophy should above all be a method of cognition rather than an all-encompassing outlook. Ilenkov was not allowed to teach at MGU, and the publication of his dissertation was delayed until 1960. ${ }^{23}$ Two years later Ilenkov published his celebrated article 'The Ideal', which tried to carve out a set of specifically ideal (as opposed to simply mental) phenomena and to argue the case for their objective existence anchored in human activity. (He expanded this thesis in the mid-I97os, without adding significantly to the original forcefulness of the argument.) ${ }^{24}$ It was precisely in the early I960s that Ilenkov did his best work, persistently marked by a deep interest in Hegel. The starting-point of his study of Marx's Capital was Hegel's question: 'Who thinks abstractly?' Ilenkov argued that our first encounter with an object is always an encounter with the abstract (not with the concrete, as the empiricist materialists believed), the result of an abstraction that categorises the object without being able to penetrate into the multitude of forms, processes and contradictions that the concrete life of the object involves. Thus he described Marx's thought as an ascent from the abstract to the concrete, and as an oscillation between the historical and the logical.

While an innovator in the interpretation of Marx, Ilenkov had distinctly conservative ideas in the realm of aesthetics. He was a lifelong admirer of Wagner but rejected pop art and Andy Warhol (his mistrust of pop art was shared by his older friend Lifshits). Having seen an exhibition of contemporary art in Vienna in 1964, Ilenkov came back subdued, his belief in the ability of art to serve as the vehicle of humanism severely dented. ${ }^{25}$ Rather than a dissident, Ilenkov was perhaps the best mind of the 'people of the sixties' (shestidesiatniki), the generation that came on the crest of the shortlived 'thaw' and suffered throughout the years of Brezhnev's stagnation without giving up its hope that the system could be reformed from within. Having prepared in the mid-I970s a typewritten translation of Orwell's 1984, Ilenkov still believed that this was a book tracing the latent tendency towards totalitarianism in capitalist societies, not a communist dystopia. ${ }^{26}$ 
Not much younger than Ilenkov, but with his formative years spent in a very dissimilar way, Mamardashvili largely shared Ilenkov's non-dissident orientation, yet he did not intend his work in philosophy as a tool for the renewal of Marxism. If anything, Mamardashvili's philosophising (much of it done in the form of lectures rather than in print) signalled the end of Soviet Marxism's claim to an intellectual monopoly. The gulf between his and Ilenkov's disposition probably stemmed from the fact that Mamardashvili was still too young to be called up during the Second World War; furthermore, his Georgian upbringing and his early love for French culture were reasons enough for him to be perceived as more cosmopolitan and less prepared to get immediately involved in the civic agenda of Soviet philosophy. Touched by privilege and luck, Mamardashvili served in the I96os on the editorial staff of the Prague-based journal Problems of Peace and Socialism. He could travel to France and Italy, made the acquaintance of Althusser (with whom he later corresponded and met on occasion), and became an admirer of jazz and Proust. Philosophically, too, Mamardashvili thought he had moved away from Ilenkov by turning his back on the dominant influence of Hegel. In fact, he referred to Ilenkov's philosophy as 'too Hegelian'. ${ }^{27}$ This, however, could not conceal the fact that Mamardashvili's first book, Forms and Content of Thinking (1968), drew inspiration precisely from Hegel in order to articulate an understanding of consciousness as a supra-individual phenomenon that has its binding forms (objective Spirit), existing as it were in 'estrangement' from the consciousness of the individual. Ironically, it was this antipsychologism, which Mamardashvili learnt from Hegel and Marx rather than from Husserl, that later guided him to question their idea of 'iron necessity' and to ask how we can avoid nihilism if we admit that our actions are causally determined. In the words of an astute Russian commentator, Mamardashvili's question became how to reconcile a scientific (Marxist) approach to history and consciousness 'with the phenomenon of freedom, the uniqueness of our personality, our dignity'. ${ }^{28}$ In his bid to solve the conundrum, Mamardashvili outlined a typology of rationality, which forms the focal point of what is probably his best book. ${ }^{29}$ The 'classic ideal of rationality' separates the thinking subject from the reality he aspires to know. This is meant to be a guarantee of the objectivity of knowledge, but it actually amounts to a crippling dualism: the thinking human being is pushed as if beyond and outside the world he strives to understand; all his subjective experiences are also expelled in the process. The 'non-classic ideal of rationality' restores to the individual his lawful place in the world. As the thinking person gets reinstated as an integral part of reality, consciousness and cognition cease to be a reflection (and even refraction) of that reality; they are now 
seen ontologically, as events that take place and unfold in the world. Consciousness becomes an effort, a creative act that no longer tries to banish our subjective experiences; instead, it underwrites the existence of freedom. In his lectures on Proust (1984-5) Mamardashvili took this argument further, demonstrating that in the creative event of consciousness the past, present and future are no longer clearly demarcated. Were it not for our effort, the future might not come to be; it is not simply available to us in the mode of ontological certainty. On the other hand, in the act of a creative effort (consciousness) the past may come alive once again. This is where Mamardashvili begins to leave behind Soviet Marxism as a cultural and social project. On the surface, his assertion of human effort and activity is only a reformulation of Marx's famous theses on Feuerbach. In truth, Mamardashvili's praise of effort is also an admission of uncertainty, an embrace of open-endedness, coloured by an optimistic vision of selffashioning but equally tinged by an anxious realisation that the pursuit of happiness cannot be a collective project.

What is even more significant for our argument is the fact that with Ilenkov and Mamardashvili Soviet Marxism had once again reached the point - for the first time since the I930s - of self-reflexive engagement with the non-Marxist philosophical tradition in Russia. (In 1943 the mediocre but powerful Party philosopher Iovchuk had organised the first Soviet chair in the History of Russian Philosophy, ${ }^{30}$ but this amounted to little more than fuelling Russian nationalism while guarding the purity of MarxistLeninist dogma.) In the latter half of the I950s Ilenkov was the centre of a circle of young intellectuals - many of them later to confirm their credentials as conservative and even nationalist thinkers - which included, among others, Davydov, Kozhinov, Gachev, Bocharov and Palievsky. ${ }^{3 \mathrm{I}}$ Ilenkov's essay of that time, 'Cosmology of Spirit' (first published posthumously in 1988), has been interpreted as exhibiting a number of parallels with Fedorov's anti-positivist and anti-individualist philosophy of nature, although the question of whether Ilenkov had actually read Fedorov remains open..$^{32}$ It is well documented, however, that he was familiar with the work of the Bakhtin Circle, displaying enthusiasm for Medvedev's The Formal Method in Literary Scholarship (1928) but remaining indifferent towards Bakhtin's Problems of Dostoevsky's Poetics (1963). ${ }^{33}$

More importantly, while Ilenkov did not sympathise with the Slavophiles and, provoked by Kozhinov, voiced disapproval of both Ivan Kireevsky's works and his countenance, ${ }^{34}$ his view of Marxism as the offspring of a long western cultural tradition (he called Marx a 'son of the West' and described Lenin in exactly the same words $)^{35}$ no doubt implied a certain antagonism 
between Marxism and the currents of Russian thought whose legacy had come to be tested after the Revolution. Unlike Berdiaev, Ilenkov did not hold Communism to be the organic outgrowth of specific eastern (Russian) circumstances; but in calling Lenin a 'son of the West' he nonetheless evoked the old framework of opposition between Westernisers and Slavophiles that had served to organise the discussion of Russian intellectual life for several decades before I9I7.

Mamardashvili shared Ilenkov's suspicion regarding a Russian Sonderweg in philosophy. He places Chaadaev at the beginning of modern Russian thought, but notes at the same time that Chaadaev failed to generate a tradition; his work faded without yielding further impulse. Philosophy as an autonomous enterprise, Mamardashvili believed, commenced with Solovev. Not unlike Shpet before him, Mamardashvili was convinced that philosophy cannot exist and flourish where the struggle for social justice takes the upper hand. This is why he contends that Russian philosophy either never existed, or only began to emerge at the end of the nineteenth century, denying Soviet philosophy autonomy and considering it part of what he terms, borrowing from Althusser, 'the ideological state apparatus'. Mamardashvili was equally sceptical of the time-honoured practice of substituting nineteenth-century Russian literature for philosophy; in particular, Dostoevsky was to him a helpless 'idiot' as soon as he moved on to the level of philosophical reflection. Tolstoy, on the other hand, was granted the status of a great religious thinker. ${ }^{36}$

The singling out of Solovev as the inceptor of autonomous Russian philosophy is not accidental. While careful to distinguish between Russian philosophy and Russian literature, Mamardashvili - despite his pronounced secularism and predilection for western philosophy - is more willing to see the complex mediations between philosophy and religious thought in the Russian context. The two, he believed, intersected and overlapped above all in the field of eschatology. The 'eschatological note' continued to be present into the I920s, embodied by thinkers and writers shaped by the Silver Age. ${ }^{37}$ In the same lecture, delivered in Leningrad on 2 December 1988, Mamardashvili paid tribute to a host of Russian religious thinkers, notably Berdiaev, Shestov and, above all, Rozanov, whose Apocalypse of Our Time received special praise. ${ }^{38}$ Thus instead of drawing an impenetrable boundary between philosophy and religious thought in Russia, Mamardashvili essayed to see them as discursive formations that often occupied the same territory and were involved in a dialectic of exchange and competition. 
If Soviet Marxism was thus able to remain in dialogue with non-Marxist Russian thought, or at least to exhibit a degree of self-awareness and reflexivity vis-à-vis the traditions of pre-I9I7 Russian thought, other intellectual currents were much more prominent in their role as guardians of the tradition. In addition to a host of nineteenth-century intellectuals actively appropriated and often interpreted in a rather strained fashion by Soviet Marxism as early exponents of revolutionary thinking (Belinsky, Herzen, Chernyshevsky, Pisarev), a wider alternative corpus of Russian thought was gradually being reassembled in the Soviet Union. At first, this included solely nineteenth-century thinkers and writers: five previously unknown 'Philosophical Letters' by Chaadaev were published as early as 1935, along with Leontev's autobiography (all in vols. 22-4 of the prestigious series Literaturnoe nasledstvo). Later, during the 'thaw' years, Lossky's and Zenkovsky's histories of Russian philosophy appeared in the Soviet Union in small print runs (in 1954 and 1956 , respectively); dissemination was restricted on both occasions to people in the Party hierarchy and to those entrusted with leading positions in Soviet ideological life.

The rediscovery of Russian religious thought began in earnest in the late I960s and early I970s, with a series of articles written for the five-volume Soviet Philosophical Encyclopaedia by Losev, Averintsev, Asmus, Khoruzhy and others. The article on Solovev in the final volume (1970) was, much to everybody's surprise, longer than even the entry on Engels. ${ }^{39}$ This particular volume also contained articles on Khomiakov, Florensky, Shestov, Fedorov and other religious thinkers, all of them written informatively and in a respectful tone. A two-volume edition of Skovoroda's works appeared in 1973, followed by a volume of Kireevsky's writings in 1979. The first half of the I980s saw editions of some of the essays of Konstantin and Ivan Aksakov, but probably the most tumultuous event of the 1980s, still before Gorbachev commenced his reforms in 1985, was the appearance in 1982 of a volume of selected essays by Fedorov, edited by the renowned Kant and Schelling scholar Arseny Gulyga and withdrawn from the bookshops soon after publication. ${ }^{40}$ Together with Losev (who by the time of his death in I988 had managed to write a short introduction and a more extensive book on Solovev) ${ }^{41}$ Gulyga had started work in the rig7os on a three-volume edition of Solovev's principal works, which was to materialise as a two-volume selection in 1988. The same year saw a Politburo resolution decreeing that a series of republications of Russian non-Marxist philosophy be launched in 1989. Berdiaev, Shpet, Bakunin, Chaadaev, Florensky, 
Frank, Rozanov, Losev, Kropotkin, Ern, Iurkevich, as well as the important collective volumes Landmarks and Out of the Depths, were all published in this series in 1989-9I.

Crucially, however, this chronology of rediscovery must not conceal the fact that, as Vladimir Smirnov notes in his memoirs of Asmus, the pre-1917 editions of Russian philosophy had actually always been freely available in the public libraries; they never formed part of the special depositories and, what is more, in the years following the Second World War these pre-I9I7 editions could also be bought in second-hand bookshops. ${ }^{42}$ When at the beginning of the 1970 clandestine religious circles began to be formed in Leningrad, the works of Berdiaev, Florensky and Sergey Bulgakov were all discussed in the meetings (attended sometimes by thirty to fifty people). ${ }^{43}$ Similarly, when the organised meetings of the Anthroposophical Society resumed in Moscow in 1969, Russian and western pre-1917 works were once again read and examined. ${ }^{44}$ Russian pre-1917 thought was thus revived and studied in waves of appropriation and accommodation that were no doubt politically conditioned and subject to considerable censorship but had nonetheless been in evidence long before the more propitious time of the rig8os.

Let me illustrate this argument with a brief look at the appropriation in the Soviet Union of two powerful pre-I9I7 discourses of exceptionalism, Slavophilism and pochvennichestvo. For some two decades after 1917, Slavophilism seemed entirely forgotten; its conservative charge meant that it was considered squarely incompatible with the tenets of Soviet ideology. In the early 1920s, while ideological control was still rather lax, Shpet famously claimed that it was the Slavophiles who had formulated 'the only original problems of Russian philosophy'. ${ }^{45}$ Bakhtin, in his lectures on Russian literature given privately in the I920s, recommended Slavophilism as 'a significant phenomenon in the history of Russian thought', calling Westernism 'just a soap bubble that produced nothing but phrases before bursting. ${ }^{46}$ At the State Academy of Artistic Sciences (GAKhN), where Shpet served as Vice-President from 1924 to 1929, Losev gave in March 1928 an apparently intriguing paper on the aesthetics and language theory of Konstantin Aksakov. ${ }^{47}$ Yet it was only in the late 1930s, as Stalin's politics of russification and nation-building gathered pace and the discourse of narodnost' surfaced once again in public discussions, that Slavophilism was put on the agenda in earnest. The key issue was how to evaluate Slavophilism historically, how to discern - from a Marxist perspective - the progressive and the retrograde in the platform of the Slavophiles. This debate began in 1939 with an article by Nikolay 
Druzhinin, on 'Herzen and the Slavophiles', in which he made the telling (but inaccurate) claim that no research had been published on the Slavophiles since 1917. ${ }^{48}$ Two years later Sergey Dmitriev contributed to the same journal an article which, while branding Slavophilism 'a variety of reactionary-nationalist Romanticism', took the liberty of noting some progressive features and concluded that, objectively, the Slavophiles were in favour of a 'Prussian route' for Russian capitalism. This relativisation of the opposition between Slavophiles and Westernisers was a novel element, and it was unambiguously criticised in the ensuing discussion. ${ }^{49}$

The mainstream view of the Slavophiles as upholders of tradition and thinkers with unmistakably conservative leanings was not overturned during the 1940s, but it was defended with arguments that could potentially destabilise the official ideology. Lidiia Ginzburg, one of the most distinguished liberal intellectuals of the Soviet age, turned her attention in a book published in 1940 to Lermontov, ${ }^{50}$ who knew Samarin and Khomiakov and whose poetry was favoured in Slavophile circles. In fact, Ginzburg produced arguments undermining the case for affinity between Lermontov and the Slavophiles. But while doing that, she arrived at a subversive version of the official Soviet literary canon. According to Ginzburg, in the I84Os there was a trend among the left-wing Westernisers to prefer Lermontov, in contrast to a distinctive Slavophile preference for Pushkin. ${ }^{5 \mathrm{I}}$ Thus in Ginzburg's account Pushkin's supremacy and reserved seat in the canon were subjected to scrutiny and put in question, becoming tainted by association with the conservative Slavophile camp.

Ginzburg's book is important in one more respect. It points to the fact that debates on Slavophilism in the Soviet Union would begin, as was also often the case before 1917, as debates on literature and aesthetics but would end up as debates on ideology and philosophy. This was not just because the Slavophiles were themselves literati (not very successful ones), but also because questions of identity, culture and language were so central to their endeavours and to those of the Soviet philosophers, historians and literary scholars who examined their work. Literature and aesthetics became the focal point of the second defining moment in Soviet debates on Slavophilism, and a springboard for attempts to re-evaluate the overall cultural and political significance of Slavophilism. This second discussion took place at the end of the 1960s, starting in 1968 in Problems of Literature and continuing in the same journal and in New World in 1969, the year that saw the publication in Leningrad of a representative volume of Khomiakov's poems and plays. $^{52}$ Among the participants were two literary scholars, Boris Egorov and Vadim Kozhinov, representing two very different orientations in 
the Soviet intellectual landscape. While Egorov was close to Lotman and the Tartu School (after Lotman's death Egorov wrote his biography), Kozhinov had already set off on a journey that would make him one of the principal revivers of pochvennichestvo. In the wake of the discussion, Egorov conceived an article that inscribed the culture and the outlook of the Slavophiles and the Westernisers in a wider semiotic system, thus projecting and emphasising a typological similarity rather than a set of non-negotiable differences between the two. ${ }^{53}$ Kozhinov, too, sought to relax the opposition between Slavophilism and Westernism, but he went much further than Egorov. Kozhinov saw the underlying characteristic of Slavophilism as its insistence on Russia's uniqueness and originality rather than as the espousal of traditionalism and aristocratic values. He was adamant that this doctrine had no 'political colouration'; rather, it was shared by thinkers from across the ideological spectrum: Populists, monarchists, socialists, aristocrats and democrats alike. The same variety, Kozhinov believed, could also be observed within Westernism. This invites the conclusion that no ideological watershed' ran between Slavophilism and Westernism as such: they both strove to 'understand objectively the essence of Russia's historical path and culture'; each of the two grasped certain aspects of the truth, while missing others. ${ }^{54}$ (This complementarity no doubt reminds the reader of Berdiaev's dictum: 'both sides loved Russia; the Slavophiles as a mother, the Westernisers as a child'.) $)^{55}$ Drawing on Kireevsky, Kozhinov submits that the Slavophiles continued the Platonic rather than the Aristotelian line in philosophy; their suspicion vis-à-vis the undivided authority of rationalism and the seminality of abstract thought and their attention to a holistic notion of the human being enabled them to foreshadow certain features of twentieth-century Existentialism. On the other hand, their organic vision of the people, of a historically evolving collectivity, and of the need to enrich the life of the people with the practical benefits of philosophy separated them clearly - and safely - from the Existentialists. The Slavophiles were admittedly idealists, but that was no reason to disqualify and exclude them from the history of Russian thought, where idealism (as opposed to materialism) was the ground 'on which a plethora of deep philosophical discoveries were born, which were needed by mankind'. ${ }^{56}$

This forceful rehabilitation of the Slavophiles at the end of the I96os marked at the same time the beginning of the revival of pochvennichestvo in the Soviet Union, a process that by the end of the I980s was drawing into its orbit not just Kozhinov, one of the inveterate 'pochvenniks or neoSlavophiles' (as Bakhtin called Kozhinov, while trying to shield him from accusations of anti-Semitism), ${ }^{57}$ but even the renowned historian of western 
(in particular German) philosophy Arseny Gulyga. During the late I970s and early 1980s Gulyga gradually refocused his attention on Russian nineteenth-century thinkers (Fedorov and Solovev), joined the proponents of Russian exceptionalism, contributing to the conservative periodical Our Contemporary an essay that read at the time like a catalogue of nationalist demands, ${ }^{58}$ and eventually arrived - while maintaining that he was no religious 'fanatic' - at a preference for Russian Orthodoxy as a form of Christianity that 'endows man, more than western versions of Christianity, with freedom of will'.59 In an article written in 1990, he asserted that the philosophical centre of the world had been shifting towards Russia since the I870s, a process that lasted until the I920s, thanks to the universality of Russian religious thought and its three distinctive features: love, faithinformed collectivity (sobornost) and cosmic addressivity. ${ }^{60}$

The reawakening of the conservative idea of Russian uniqueness sometimes drew explicitly on emblematic nineteenth-century Russian thinkers and writers, chiefly Dostoevsky (although, as the work of the liberal Grigory Pomerants demonstrates, Dostoevsky was not the exclusive property of the exceptionalists). ${ }^{\mathrm{I}}$ Iury Davydov, another intellectual who had begun as an expert in, and connoisseur of, German thought and had written illuminating pieces on Spengler and Max Weber, remobilised Dostoevsky's well-known praise for the Russian spirit as naturally - and uniquely - disposed towards 'all-humanness' (note the tension between universalism and uniqueness in this claim). All nations, Davydov wrote in 1982, borrowing from Dostoevsky's arguments, are inherently orientated towards universality; they all exist in a dual mode, poised between the native soil and the moral absolute of 'all-humanness'. Each nation has its own destiny and its own path towards universality. From this Davydov inferred that different nations are likely to travel at a different pace and to find themselves at different stages on their journey to the moral absolute. ${ }^{62}$ The West, once united with Russia by the sublime moral idea inviting self-sacrifice for the all-human good, had long since given up the goal of attaining the absolute, and all that is left behind are the dead monuments of its past greatness of spirit; this is how Davydov (following here Spengler) interprets Ivan Karamazov's desire to visit Europe, that 'dear cemetery'. Russia's destiny, on the other hand, is to complete the journey, to attain for the world the moral absolute that all nations are called upon to seek, but only a few (one, in Davydov's account) can really reach. Turning to Dostoevsky's The Devils, Davydov evokes Shatov's conviction of the uniqueness of the Russian people: 'If a great people does not believe that in it alone the truth resides (in it alone and exceptionally in it), if it does not believe that it alone is able and called to 
resurrect and save all through its truth, then it ceases immediately to be a great people and turns at once into ethnographic material rather than a great people. ${ }^{\prime 3}$ Davydov's messianism is thus nurtured by Dostoevsky's appeal to Russia as the sole surviving nation that is immediately involved in the pursuit of the moral absolute; no one else accompanies the Russian people on this arduous journey, and they alone are destined to a self-sacrificial struggle on behalf of all other peoples. Davydov's original (albeit not very convincing) twist to this otherwise trite story is the attempt to revise and smooth out the opposition between Dostoevsky and Tolstoy (the classic statement of which was worked out in the Silver Age, notably by Merezhkovsky, and had since become one of the topoi of aesthetic conservatism, not least in Germany, where it was adopted by Moeller van den Bruck and Spengler). Tolstoy is now positioned not as an antagonist but as the receiver of a set of shared values which his heroes materialise. The moral resurrection that was beyond the reach of Dostoevsky's 'demonic' characters is achieved by Tolstoy's protagonists, shot through by ideas of labour, soil and solidarity. ${ }^{64}$ What is more, Davydov produces here a direct link between Tolstoy and the 'great moral philosophy' that allegedly informs the works of Astafev, Rasputin and other conservative writers of the 'village prose' movement. In praising them, he declares himself against the "abstract-"globalist", or 'universal-"cosmic", understanding of the world, implying a move backwards to the time-honoured and 'truly moral' love for the real (Russian) world of one's neighbours, one's kin and one's colleagues (Davydov chooses the obsolete form sosluzhivtsev). ${ }^{65}$

This elevation of Russian literature of the nineteenth century to a reservoir of indispensable philosophical ideas, the desirability of which Davydov notes in his book ${ }^{66}$ (and the undesirability of which Mamardashvili, as we have seen, highlights with reference to Dostoevsky), had been a feature of the restoration of discourses of exceptionalism since the late 196os. At that time Georgy Gachev, drawing inspiration from Tiutchev (arguably the poet he quotes most frequently), Danilevsky, Spengler, Gumilev and Dostoevsky (whose 'cosmos' he discussed in an early essay), ${ }^{67}$ began to explore the elusive entity that he termed 'cosmo-psycho-logos', an indivisible and primordial unity of psychology, language and specific world outlook characteristic of each nation and manifest in the various forms of national life. Starting in January 1967 , Gachev wrote down his lectures, in the form of dialogue, on the everyday embodiments of national cultures (food, sound, bodily movements, home interiors and exteriors, etc.). Earlier, in 1966, he had laid the foundations of his long-term project with an article on 'Language as the Voice of a Nation's Essence'. Gachev's approach was disarmingly eclectic: 
a mixture of (implicit) Slavophile admiration for the Russian language, a German Romantic confidence in language as capable of conveying directly the original features of a nation's psyche and a self-confessed revival of the ancient Greek doctrine of the four elements (earth, water, air and fire), which, in different combinations and with different specific weights, are present in the metaphoric arsenal of each language, giving this particular language its own uniqueness. Gachev's work leaves the impression of an uncontrollable play of associations. He is sometimes witty, sometimes excruciatingly dilettantish (and often both). Among his signature 'discoveries' is the metathesis 'mother-darkness' (mat'-t'ma), establishing a rich field of associations between femininity, birth and depth, night, opacity and secrecy (ultimately their identity), of which the Swiss anthropologist and cultural historian Bachofen would no doubt have approved. "Matter" (a philosophical category) originally means a beginning, maternal and dark', Gachev concludes, exploiting the alliteration built on mat ${ }^{68}$ Language is seen by Gachev as a 'portable cosmos'; one does not need to travel abroad to 'grasp another nation's mentality: one simply needs to listen to that nation's language'. ${ }^{69} \mathrm{He}$ is thus torn between an ultimately soil-rooted view of national cultures and a realisation of the potential of language to liberate these cultures from the confines of their monadic existence.

Because nations present different cosmo-psycho-logic entities, they also have different images of the world and of other nations. These images mirror the claim to uniqueness that all nations seem to enjoy in Gachev's cultural theory. Gachev is not a straightforward exceptionalist. At first sight, Russia's claim to uniqueness is as legitimate as that of any other nation. Where Gachev does part company with this tolerant view is in the adoption and propagation of a xenophobic and at times anti-Semitic philosophy of Russian history. He proffers a 'negative' version of exceptionalism: unlike any other great nation, Russia has always been in need of a strong foreign ruler: TataroMongols, Germans (during Peter the Great's reign), 'the German-Jewish socialism' of Lenin's time, 'the Georgian Dzhugashvili' and then a string of Ukrainian leaders (khokhly-malorossy, in Gachev's language), beginning with Khrushchev. ${ }^{70}$ The collapse of the Soviet Union was judged by Gachev to be both a loss (of empire) and a gain (of the autonomy of nationhood), a dialectical give-and-take between Rossiia and Rus'.

This oscillation between empire and nation also marked the writings of Lev Gumilev, especially during his later years. His work is important for our argument, as it reveals the complex modifications of émigré Eurasianism and the ensuing (dis)continuities informing Gumilev's understanding of Russian history. The son of Nikolay Gumilev and Anna Akhmatova (suffering 
over many years a traumatic estrangement from his mother), Gumilev was arrested four times and spent years in the Gulag, eventually enjoying relative stability and freedom of research after 1956 and even a spell of autumnal glory during the late I980s and early I990s (still fostered today by his numerous followers in Russia). Best known for his book Ethnogenesis and the Biosphere of the Earth, defended as a second doctoral dissertation in 1974 but only published officially in $1989,{ }^{71}$ Gumilev owed much to Danilevsky and, with considerable qualification, also to some of the inter-war representatives of Eurasianism (mostly to Savitsky, Vernadsky and, to a lesser extent, Nikolay Trubetskoy). Danilevsky's line can indeed be traced throughout the history of Eurasianism (originally an intellectual movement of Russian émigré intellectuals founded in Sofia, influential at various points among segments of the emigration in Prague, Paris, Belgrade, the Baltic and China (I92I-38), then resurrected in post-Soviet Russia in a version that exhibited only limited similarity with the pre-Second World War Eurasian platform). Trubetskoy took for granted Danilevsky's fragmentation of history into relatively insulated cultural types. ${ }^{72} \mathrm{He}$ also shared Danilevsky's scepticism regarding the existence of 'universal civilisation' ('Universal civilisation does not and cannot exist', Danilevsky wrote), ${ }^{73}$ developing this statement into a battle cry against what he termed the 'cultural imperialism' of the Germano-Romanic type. Savitsky, on the other hand, embraced Danilevsky's interest in the spatial aspects of history, introducing the concept of mestorazvitie ('place of development' but also 'place that develops') to address the specific environment that enables the evolution of a given cultural-historical type and itself changes with the latter's development. ${ }^{74}$ Gumilev accepted Danilevsky's thesis of the essentially closed existence of the cultural-historical types, although he did recognise that at times a symbiosis between different ethnic communities is possible. But at the same time he distanced himself from the very notion of type: the entity that conformed to the self-sufficient mode of existence envisaged by Danilevsky was the ethnos, not the cultural-historical type. This substitution signalled Gumilev's determination to write from the standpoint of the exact sciences, which he considered superior to the humanities. The introduction of the ethnos as the basic unit of analysis went hand in hand with a staunch determinism that saw no room for free will, perfection or modification. Unlike Savitsky (with whom Gumilev corresponded from I956, two decades after Savitsky had ceased working actively on his Eurasian doctrine, until the latter's death, although they met only once, in I966 in Prague), ${ }^{75}$ Gumilev was interested in the cosmic and biological factors shaping history (or, more appropriately, the 'course of events'), much less so in the geographical environment or the economic framework. 
Gumilev inherited from Danilevsky (and Spengler) the belief that each particular ethnos (cultural type; civilisation) existed only for a limited time. The question for him was not whether an ethnos would fade away, but rather how it came to be in the first place. The explanation he offers, despite his claim to scientific rigour, cannot be tested or falsified, and it very much betrays a style of reasoning characteristic of an essayist claiming for himself the honourable title of 'ethnosopher' (Savitsky preferred to call himself not a geographer but a 'geosopher'). According to Gumilev, the ethnogenesis should be attributed to a cosmic push that transmits 'passionarity' (passionarnost), the creative energy that compels the human species to act against the instinct of self-preservation and thus propels them into new, previously unavailable and uncharted territories. The great conquests take place when an ethnos is at the peak of its passionarity; then the phases of 'inertia' (much like Spengler's 'decline') and 'obscurity' follow, until in the end an ethnos disappears altogether. ${ }^{76}$ None of this, of course, was part of classic Eurasianism. Although he flirted with the title of 'the last Eurasian', 77 Gumilev insisted that his theory of passionarity, combining as it did cosmic impulses and genetic pools in order to explain the fate of different ethnic collectives, was completely novel compared with the much more traditional humanistic outlook of the Eurasians. In this respect, he was no Eurasian at all, for his overall episteme was indeed rather different. ${ }^{78}$ And yet, like the Eurasians, he believed in Russia's suitability to develop as a complex 'superethnos' (empire of different peoples and races, in the language of the prewar Eurasians); like Vernadsky, he also evaluated positively the Mongol invasion, interpreting the ensuing regime not as a yoke but as a symbiosis that proved beneficial for Russia (while discarding Kievan Rus as too European). Finally, he, too, was full of suspicion when it came to the role played by the West: while the Russian ethnos was compatible with the Turkic, the West was no partner for Russia. Continuing Trubetskoy's assault on 'Germano-Romanic' civilisation, Gumilev prophesied: 'The Turks and the Mongols can be genuine friends, but the English, the French and the Germans, I am convinced, can only be cunning exploiters ... Let me tell you a secret: if Russia is to be saved, then it will only be as a Eurasian power, and only through Eurasianism. ${ }^{179}$

\section{E P I L O G U E}

Philosophy and social thought in the Soviet Union were, in the fitting words of Evert van der Zweerde, ${ }^{8 \circ}$ the product of a specific historical culture. When it comes to the social settings in which philosophy operated, 
the Soviet regime was justly criticised as oppressive. ${ }^{8 \mathrm{r}} \mathrm{A}$ look at the historical durée, however, might suggest a rather dispiriting continuity. Examining the processes of philosophical education, Frances Nethercott has established substantive parallels between the Soviet Union and tsarist Russia. As in the Soviet Union, the teaching and the study of philosophy in nineteenthcentury Russia was far from unconstrained. It was severely limited at the universities following the Decembrist uprising of 1825 , banned after I848, resurrected in 1863 and banned again in 1884 , to mention only a few of the disturbingly many milestones along the road. ${ }^{82}$ These successive 'hot and cold showers', as Nethercott puts it, led to the spontaneous formation of informal circles, of a philosophical 'underground', where the quality of instruction, or of production for that matter, was not necessarily high. The true legacy of the Soviet intellectual culture may thus be the cultivation of an emerging civil society, the grass-roots reform of the public sphere that at least two generations of dissidents have shouldered since the I96os, preparing Russia for the non-patriarchal age of freedom without guidance or guarantees. As the post-Soviet years confirm, however, things have proved to be much more complicated. The discourses of exceptionalism continue to thrive, rivalled by the comparatively feeble voices of liberal or democratic pluralism. At the same time, the intellectual attractiveness of Marxism seems to have faded for all but a small minority.

Yet sifting through the debris of Soviet Marxism - or its illicit hybrids that were undermining Marxist orthodoxy from within - one might still stumble upon veritable examples of high intellectual endeavour that deserve to survive the tectonic shifts of history. I wish to conclude by mentioning briefly a fascinating and rare case of continuity, as early as the late I960s, between Soviet Marxism and earlier Soviet thought, a case where what was meant as a bona fide piece of Marxist historical science ended up transcending the boundaries of disciplines and crushing the shell of orthodox Marxism. Boris Porshnev, arguably the most sophisticated Russian philosopher of history to emerge during the second half of the twentieth century, wrote in the late 1960s On the Beginning of Human History, a book published posthumously in an abridged version. ${ }^{83}$ With this book, Porshnev, an early Soviet admirer of Foucault and at the time already enjoying international recognition as a historian of seventeenth-century France (more so abroad, where he had earned praise from Fernand Braudel, than in the Soviet Union, where many of his colleagues considered him a dogmatic, if not an outright, Stalinist, while others ridiculed him as an indefatigable enthusiast for the Yeti) ${ }^{84}$ ventured into an area which he termed 'paleopsychology'. Designed as the middle part of a large three-part 
work to be titled A Critique of Human History, ${ }^{85}$ the book was intended to address the question of anthropogenesis, thus establishing (in fact, shortening radically) the true duration of human history and using this new premise to address the law of acceleration that Porshnev believed to be at work, as well as its implications for Marxism and for communist society. Although often questionable in its anthropological hypotheses, Porshnev's book - indeed his entire unfinished project - displayed a major forte: in marrying history and paleopsychology, Porshnev was committed to historicising the very foundation of history - the human species that had so far been taken as an immutable substance. He found support in the work of Nikolai Marr (whose semantic paleontology informed the study of language, folklore and prehistoric artefacts in the 1930s, and whom Porshnev praised openly at a time when Marr's ideas had long been confined to oblivion by the establishment), ${ }^{86}$ as well as in Pavlov's theory of the 'second signal system', Ukhtomsky's 'dominant' and Vygotsky's model of the development of consciousness in the child. Yet Porshnev was interested not only in historicising the human species, but also - equally important in locating the inner propeller and mechanisms of history. In an article sketching what was envisaged as one of the central arguments of the trilogy, Porshnev, drawing on his earlier work on social psychology, contends that human history can be explained from the workings of suggestion (suggestiia), the nuclear psychic activity (but also for Porshnev the nuclear act of oppression) that made man distinguishable from the animal kingdom. Human history is interpreted by Porshnev as an epic struggle between consecutive series of socially produced suggestions (involving corresponding acts of counter-suggestion). ${ }^{87}$ Not class struggle as such, but the pushpull sequence of suggestion and counter-suggestion is the constantly working engine of history. The alienation of man from man under capitalism is only a variety of a large-scale counter-suggestion, a manifestation of which Porshnev sees in the introduction of more advanced money-based (i.e. increasingly indirect) relationships. In this context, laughter, just as in Bakhtin, has a dual nature for Porshnev, too: it acts as a mechanism of suggestion (team- and nation-building, where Porshnev also notes the role played by feasts, collective celebrations, excessive eating and drinking), but also as a mechanism of counter-suggestion (parodying and excommunicating others, instilling suspicion or a sense of superiority against a rival community or vis-à-vis a 'sacred' message), revealing its joyfulness and oppressiveness in the same breath. ${ }^{88}$ This incessant struggle which man has waged right from the start of history (in Porshnev, there is no 'golden age' of primitive freedom and equality) is supposed to end only with 
communism, when science and the truthfulness of Marxism would finally remove the need for man to sift the environment and the information one constantly receives through the 'filter of mistrust'.

If this sounds too optimistic or too naïve, it is no more so than any other prophecy about the end of history - which might serve as a reminder that the history of thought in the Soviet period, too, should remain open, as a source of inspiration and admonition.

\section{NOTES}

I. See Michael Hagemeister, Nikolaj Fedorov: Studien zu Leben, Werk und Wirkung (Munich: Otto Sagner, 1989), pp. 24I-457; Hagemeister, 'Russian Cosmism in the I920s and today' in Bernice Glatzer Rosenthal (ed.), The Occult in Russian and Soviet Culture (Ithaca and London: Cornell University Press, 1997), pp. I85-202; Anastasiia Gacheva, 'Religiozno-filosofskaia vetv' russkogo kosmizma' in A. Gacheva, O. Kaznina and S. Semenova, Filosofskii kontekst russkoi literatury 1920-1930-kh godov (Moscow: IMLI RAN, 2003), pp. 79-I25; Svetlana Semenova, Filosof budushchego veka: Nikolai Fedorov (Moscow: Pashkov dom, 2004), pp. 463-553. For Berdiaev's impact on VSKhSON, see John B. Dunlop, The New Russian Revolutionaries (Belmont: Nordland Publishing Company, 1976), which contains an analysis and a translation of the organisation's programme (its Russian text was first published by Dunlop a year earlier in Paris), as well as the account of one of VSKhSON's leaders: Evgenii Vagin, 'Berdiaevskii soblazn ("Pravye" v oppozitsionnom dvizhenii 60-70-kh godov)', Nash sovremennik, 4 (I992), I72-8 (Vagin also mentions the importance of Frank, Solovev and Fedotov).

2. See Boris Egorov, Zhizn'i tvorchestvo Iu. M. Lotmana (Moscow: Novoe literaturnoe obozrenie, 1999), p. I40.

3. See V.S. Bibler, Mikhail Mikhailovich Bakhtin, ili Poetika kul'tury (Moscow: Progress, 199I); see also Caryl Emerson, The First Hundred Years of Mikhail Bakhtin (Princeton University Press, 1997), pp. 274-5.

4. A. Losev, Dialektika mifa (Moscow: Mysl', 200I), p. 63. See also James P. Scanlan, Marxism in the USSR. A Critical Survey of Current Soviet Thought (Ithaca and London: Cornell University Press, 1985), p. I2.

5. See more in L. A. Kozlova, 'Institut Krasnoi Professury (I92I-1938). Istoricheskii ocherk', Sotsiologicheskii zhurnal, I (1994), 96-II2.

6. See Gustav Wetter, Dialectical Materialism. A Historical and Systematic Survey of Philosophy in the Soviet Union, trans. Peter Heath (London: Routledge \& Kegan Paul, 1960), p. 525 .

7. M. B. Mitin, Filosofskaia nauka v SSSR za 25 let. Doklad, prochitannyi na sessii Akademii nauk SSSR. I8 noiabria 1942 g. (Moscow: Ogiz; Gospolitizdat, I943), p. 22.

8. Iu. P. Sharapov, Litsei v Sokol'nikakh. Ocherk istorii IFLI-Moskovskogo instituta istorii, filosofii i literatury imeni N. G. Chernyshevskogo (I93I-194I gg.) (Moscow: AIRO-XX, 1995), p. 26. 
9. For this list, see John Somerville, Soviet Philosophy: A Study of Theory and Practice (New York: Philosophical Library, 1946), p. 235.

Io. For an English translation, see [A. A. Bogdanov], Bogdanov's Tektology [Book I], ed. Peter Dudley (Hull: Centre for Systems Studies, I996).

II. A. M. Deborin, Lenin kak myslitel', 3rd expanded edn (Moscow: Gosudarstvennoe izdatel'stvo, 1929), p. 26.

I2. P. Iudin, Georgii Valentinovich Plekhanov (K 25-letiiu so dnia smerti) (Moscow: OGIZ; Gospolitizdat, 1943), pp. I8, 20.

13. See in this regard Valentin Asmus's major work, Ocherki istorii dialektiki v novoi filosofi (Moscow and Leningrad: Gosudarstvennoe izdatel'stvo, 1930). In his review of the book, Berdiaev was so impressed with Asmus's knowledge and philosophical culture that he thought Asmus was an adherent of Marxism 'solely by accident' (quoted in V. V. Sokolov, 'V. F. Asmus i dramaticheskie momenty ego filosofskogo tvorchestva i filosofskoi zhizni', Voprosy filosofi, 2 (2009), 97-IO2, here 99).

I4. See George L. Kline's 'Introduction' in Kline (ed.), Spinoza in Soviet Philosophy (London: Routledge \& Kegan Paul, 1952), p. I.

I5. For Ilenkov's planned book on Spinoza, see S. N. Mareev, E. V. Il'enkov (Moscow and Rostov-on-Don: MarT, 2005), p. 7. On his enduring fascination with Spinoza, see A. G. Novokhat'ko, 'Pochemu imenno Spinoza' in V. I. Tolstykh (ed.), Eval'd Vasil'evich Il'enkov (Moscow: ROSSPEN, 2008), pp. 70-83. In 1977, Ilenkov published in the journal Communist (under a pseudonym) a co-authored article on Spinoza entitled 'Three centuries of immortality'.

I6. See Ivan Il'in, Filosofiia Gegelia kak uchenie o konkretnosti Boga i cheloveka, 2 vols. (Moscow: G. A. Leman and S. I. Sakharov, I918); Lenin's approval of the book is recorded by Tschiževsky in Hegel bei den Slaven (Reichenberg: Gebrüder Stiepel, 1934), p. 374, n. I5.

17. See Evert van der Zweerde, Soviet Historiography of Philosophy: Istorikofilosofskaia nauka (Boston: Kluwer, 1997), p. 30.

I8. RGASPI (Moscow), f. 374, op. I, d. 5, 1. 98.

I9. G. F. Aleksandrov et al. (eds.), Istoriia filosofii, vol. III, Filosofia pervoi poloviny XIX veka (Moscow: Ogiz; Gospolitizdat, I943), p. 210.

20. On the designation 'grey horse' (seraia loshad) and the campaign against the volume, see more in G.S. Batygin and I. F. Deviatko, 'Sovetskoe filosofskoe soobshchestvo v sorokovye gody: pochemu byl zapreshchen tretii tom "Istorii filosofii", Vestnik Rossiiskoi Akademii Nauk, 63:7 (1993), 632-3.

21. For more on this and on the polemics around Hegel in the Soviet Union, see Galin Tihanov, 'Revising Hegel's phenomenology on the left: Lukács, Kojève, Hyppolite', Comparative Criticism, 25 (2004), 67-95.

22. See V. E. Evgrafov et al. (eds.), Istoriia filosofii v SSSR, vol. V, book 2 (Moscow: Nauka, 1988), pp. $38-9$.

23. It was translated into English as The Dialectics of the Abstract and the Concrete in Marx's Capital (Moscow: Progress, 1982). 
24. The most reliable version of the mid-I970s text that reflects the additions and rests on a surviving manuscript is Eval'd Il'enkov, 'Dialektika ideal'nogo', Logos, I (2009), 6-62.

25. See more on this in David Bakhurst, 'The living and the dead in Ilyenkov's philosophy' in Vesa Oittinen (ed.), Evald Ilyenkov's Philosophy Revisited (Helsinki: Kikimora Publications, 2000), pp. 23-37.

26. Ilenkov showed the translation to his close friend Mareev; see S. N. Mareev, 'Sotsializm: teoriia i praktika' in Tolstykh (ed.), Eval'd Vasil'evich Il'enkov, p. 269.

27. Merab Mamardashvili, Kak ia ponimaiu filosofiu (Moscow: Progress, 1990), p. 35. See also Nikolai Veresov, 'Vygotsky, Ilyenkov and Mamardashvili: searching for the monistic theory of mind (methodological notes)' in Oittinen (ed.), Evald Ilyenkov's Philosophy Revisited, pp. I3I-45. In a series of interviews recorded in French in November 1989, Mamardashvili confirmed his later departure from Hegel: 'German philosophy! Rise, hat off? No, for me the last interesting philosopher in Germany is Kant. Well, maybe also Schopenhauer, that's all' (M. K. Mamardashvili, 'Mysl' pod zapretom. Besedy s A. E. Epel'buen', Voprosy filosofii, 5 (1992), 100).

28. V. A. Smirnov, 'M. K. Mamardashvili: Filosofiia soznaniia' in V. A. Lektorskii (ed.), Filosofiia ne konchaetsia ... Iz istorii otechestvennoi filosofii: XX vek, 2nd edn (Moscow: ROSSPEN, I999), vol. II, pp. 480-97, here p. 489. Smirnov's article, first published in I99I, remains probably the best concise introduction to Mamardashvili's philosophy, admirably sensitive to his evolution as a thinker.

29. Mamardashvili, Klassicheskii $i$ neklassicheskii idealy ratsional'nosti (Tbilisi: Metsniereba, 1984).

30. See Z. A. Kamenskii, 'O "Filosofskoi entsiklopedii"' in Lektorskii (ed.), Filosofiia ne konchaetsia, vol. II, pp. 43-82, here p. 68.

3I. See Mareev, E. V. Il'enkov, p. I3.

32. See ibid., pp. $25-8$.

33. See V. Kozhinov, 'Gnoseologiia i tragediinost' bytiia' in Tolstykh (ed.), Drama sovetskoi filosofii. Eval'd Vasil'evich Il'enkov (Kniga-dialog) (Moscow: [Institut filosofii RAN], 1997), pp. Ioo-6, here pp. I05-6.

34. Ibid., p. IO4.

35. See E. V. Il'enkov, 'From the Marxist-Leninist point of view' in Nicholas Lobkowicz (ed.), Marx and the Western World (University of Notre Dame Press, 1967), pp. 39I-407, here pp. 392 and 394. Ilenkov was invited to this colloquium (held in April 1966 at the University of Notre Dame) but could not attend. According to the editor of the volume, he fell ill and was 'hospitalised' (Marx and the Western World, p. xii); in the introduction accompanying the first publication of the text in Russian (Voprosy fllosofii, 1988, no. I0) it is unambiguously suggested that the authorities had actually not allowed him to travel.

36. See Mamardashvili, 'Mysl' pod zapretom', I13-I4.

37. References here are to Mamardashvili's i 988 lecture 'Filosofiia i religiia' in Mamardashvili, Moi opyt netipichen (St Petersburg: Azbuka, 2000), pp. 258-79, here p. 277. 
38. See Mamardashvili, 'Filosofiia i religiia', pp. 273-4.

39. This detail and the rest of the factual information on the publications of nonMarxist thinkers in the Soviet Union until 1991 are drawn from Stanislav Dzhimbinov, 'The return of Russian philosophy' in James P. Scanlan (ed.), Russian Thought after Communism. The Recovery of a Philosophical Heritage (Armonk and London: M. E. Sharpe, 1994), pp. II-22 (originally published in Russian in 1992).

40. Nikolai Fedorov, Sochineniia, ed. A. Gulyga (Moscow: Mysl', 1982).

4I. A. F. Losev, Vladimir Solov'ev (Moscow: Mysl', 1983) and Vladimir Solov'ev i ego vremia (Moscow: Progress, 1990).

42. See Smirnov's entry in 'V. F. Asmus - pedagog i myslitel' (materialy "kruglogo stola")' in Lektorskii (ed.), Filosofiia ne konchaetsia, vol. II, pp. 292-327, here p. 319.

43. See Evgenij A. Pazuchin, 'Studium und Entwicklung der Tradition der russischen religiösen Philosophie vom Anfang des 20. Jahrhunderts im Milieu der religiösen Leningrader Intelligenz von den 70-er Jahren bis heute' in Eberhard Müller and Franz Josef Klehr (eds.), Russische religiöse Philosophie. Das wiedergewonnene Erbe: Aneignung und Distanz (Stuttgart: Akademie der Diözese Rottenburg-Stuttgart, 1992), pp. 33-50, here p. 38. The circle in question was founded by Tatiana Goricheva in 1975; the last meeting was held in 1980. In January 1976, the circle began to issue a journal (37: the number of the apartment where the meetings took place); the poet Viktor Krivulin became one of its editors. A number of private philosophical seminars and circles in the Soviet Union are mentioned in Zweerde, Soviet Historiography of Philosophy, p. 52.

44. See Renata von Maydell, 'Die anthroposophische Gesellschaft in Russland. Entstehung (1913), Auflösung (1923) und Neugründung' in Müller and Klehr (eds.), Russische religiöse Philosophie, pp. 171-83, here p. 176.

45. Gustav Shpet, Ocherk razvitiia russkoi filosofii. Pervaia chast'(Petrograd: Kolos, I922), p. 37.

46. Mikhail Bakhtin, Sobranie sochinenii, 7 vols. (Moscow: Russkie slovari, I996-), vol. II, p. 427.

47. Losev's paper survives only as an extended summary organised around bullet points: 'Filologiia i estetika Konstantina Aksakova' (1928) in Losev, Imia: izbrannye raboty, perevody, besedy, issledovaniia, arkhivnye materialy, ed. A. A. Takho-Godi (St Petersburg: Aleteia, 1997), pp. 94-IOO.

48. N. Druzhinin, 'Gertsen i slavianofily', Istorik-marksist, I (1939), I25-45, I97-200, here I25. By the mid-I930s, Mark Azadovskii had published the correspondence between Petr Kireevsky and Iazykov (Moscow: Izdatel'stvo Akademii nauk SSSR, 1935) and an article on the two, 'Kireevskii i Iazykov', republished in a slightly altered version in his Literatura i fol'klor (Leningrad: Khudozhestvennaia literatura, 1938).

49. See S. S. Dmitriev, 'Slavianofily i slavianofil'stvo', Istorik-marksist, I (194I), 85-97. On the discussion, with contributions by fifteen speakers, see I. Ganichev, 'Obsuzhdenie doklada S. S. Dmitrieva 'Slavianofily i slavianofil'stvo'. Informatsiia o diskussii', Istorik-marksist, I (194I), 97-I00. See also Dmitriev's article 'Zapadniki i slavianofily', Molodoi bol'shevik, II (194I), 39-49. 
50. L. Ginzburg, Tvorcheskii put' Lermontova (Leningrad: Gosudarstvennoe izdatel'stvo 'Khudozhestvennaia literatura', I940). Chapter 7 is entitled 'Spor o Lermontove' and discusses Lermontov and the Slavophiles.

51. Ginzburg, Tvorcheskii put' Lermontova, pp. 219-20.

52. A. S. Khomiakov, Stikhotvoreniia i dramy, ed. B. F. Egorov (Leningrad: Sovetskii pisatel', 1969).

53. See Egorov, 'Slavianofil'stvo, zapadnichestvo i kul'turologiia' in Trudy po znakovym sistemam, vol. VI, pp. 265-75 (Uchenye zapiski Tartuskogo gosudarstvennogo universiteta, 308 (1973): Sbornik nauchnykh statei $v$ chest' Mikhaila Mikhailovicha Bakhtina (k 75-letiiu so dnia rozhdeniia), ed. Iu. Lotman). The article was first drafted in the form of theses published in 1970 (see Egorov, 'Slavianofil'stvo, zapadnichestvo i kul'turologiia' in Iu. Lotman (ed.), Tezisy dokladov IV Letnei shkoly po vtorichnym modeliruiushchim sistemam, I7-24 avgusta 1970 (Tartu: Tartuskii gosudarstvennyi universitet), pp. 88-9).

54. All quotations are from Vadim Kozhinov, 'O glavnom v nasledii slavianofilov' in V. A. Fateev (ed.), Slavianofil'stvo: Pro et Contra, 2nd edn (St Petersburg: Izdatel'stvo Sankt-Peterburgskogo universiteta, 2009), pp. 877-99, here pp. 88I-2 (first published in Voprosy literatury, IO (1969), II3-3I).

55. Nicholas Berdyaev, The Russian Idea (London: Geoffrey Bles, 1947), p. 39.

56. Kozhinov, 'O glavnom', pp. 895-6.

57. V. D. Duvakin, Besedy s Bakhtinym (Moscow: Soglasie, 2002), p. 247.

58. See A. Gulyga, 'Russkii vopros', Nash sovremennik, I (1990), I68-76. On the role of Nash Souremennik in the Soviet ideological life of the time of glasnost' and perestroika, and on the complex co-optation of nationalism in the Party agenda, see Yitzhak M. Brudny, Reinventing Russia: Russian Nationalism and the Soviet State, I953-199I (Cambridge, Mass.: Harvard University Press, 1998), pp. 199-203.

59. Arsenii Gulyga, Russkaia ideia i ee tvortsy (Moscow: Soratnik, 1995), p. I6; see also Gulyga's defence of sobornost' against the critique by liberal thinkers such as Grigorii Pomerants and Boris Groys (ibid., p. 19).

6o. See Gulyga, 'Russkii religiozno-filosofskii renessans', Nash sovremennik, 7 (1990), I85-7.

6I. See Grigorii Pomerants, Dostoevskii: Otkrytost' bezdne (Moscow: Sovetskii pisatel', 1990; first published New York, 1989); see also Pomerants's essay 'Mysliteli chitaiut Dostoevskogo', Oktiabr', 3 (1993), I85-9. Pomerants had gained popularity as a dissident defender of liberal values and an opponent of the native-soil conservative ideas of Solzhenitsyn. On the status of Dostoevsky as a thinker and for an inscription of his work in the Russian philosophical context, see James Scanlan, Dostoevsky the Thinker (Ithaca: Cornell University Press, 2002).

62. Iurii Davydov, Etika liubvi $i$ metafizika svoevoliia (problemy nravstvennoi filosofii) (Moscow: Molodaia gvardiia, 1982), p. 268.

63. This is my translation of the quotation from Besy adduced by Davydov (Davydov, Etika liubvi, p. 270).

64. Ibid., p. 273. Davydov talks explicitly about the need to revise the opposition between Dostoevsky and Tolstoy (mentioning Merezhkovsky) in the introduction to the book, p. 8 . 
65. Ibid., p. 274. On Davydov's neo-pochvennichestvo, see also Evert van der Zweerde, 'Die Rolle der Philosophiegeschichte im "neuen philosophischen Denken" in der UdSSR', Studies in Soviet Thought, 40 (1990), 66-70.

66. Davydov, Etika liubvi, pp. 6-7.

67. G. D. Gachev, 'Kosmos Dostoevskogo' in S. S. Konkin (ed.), Problemy poetiki $i$ istorii literatury (Saransk: Mordovskii gosudarstvennyi universitet imeni N.P. Ogareva, 1973), pp. IIO-24. The volume was a Festschrift on Bakhtin's seventy-fifth birthday; Gachev, together with Kozhinov and Sergey Bocharov, was responsible for the rediscovery of Bakhtin in the Soviet Union in the first half of the ig6os.

68. Gachev, 'Iazyk kak golos natsional'noi prirody' [September 1966] in Gachev, Kosmo-psikho-logos (Moscow: Akademicheskii proekt, 2007), pp. I84-208, here p. 205 , n. I.

69. Ibid., p. 185 .

70. Gachev, 'Kosmosofiia Rossii' [1990] in Gachev, Kosmo-psikho-logos, pp. 459-64, here p. 462. Gachev's appreciation of Jewish culture and thought is often dotted with outbursts of condescension and contempt (see his essay 'Evreiskii obraz mira', ibid., pp. 484-503). By 199I Gachev had prepared a 700-page typescript on the Jewish mentality (see Gachev, Mental'nosti narodov mira (Moscow: Eksmo Algoritm, 2008), p. 527). Little of it has been published to date; for more on Gachev's anti-Semitism, see Vadim Rossman, Russian Intellectual AntiSemitism in the Post-Communist Era (Lincoln: University of Nebraska Press, 2002), pp. I78-8I.

7I. There is an abridged English translation under the title Ethnogenesis and the Biosphere (Moscow: Progress, 1990).

72. Danilevsky formulated the principle of discrete cultural-historical types (ten in total) in his I869 work Rossiia i Evropa; see N. Danilevskii, Rossiia i Evropa, 6th edn (St Petersburg: Glagol, 1995), p. 73.

73. Danilevskii, Rossiia $i$ Evropa, p. IO4.

74. For more on this, see Tihanov, 'Cultural emancipation and the novelistic: Trubetzkoy, Savitsky, Bakhtin', Bucknell Review, 43:2 (2000), 47-67.

75. These facts can be found in Gumilev's biography: Sergei Lavrov, Lev Gumilev: sud'ba i idei (Moscow: Svarog i K, 2000).

76. Gumilev, Etnogenez i biosfera zemli (Leningrad: Gidrometeoizdat, 1990), pp. $288-9$.

77. See Gumilev, 'Zametki poslednego evraziitsa', Nashe nasledie, 3 (199I), I9-34.

78. This point is made very well by Marlène Laruelle in her book Russian Eurasianism: An Ideology of Empire (Baltimore: The Johns Hopkins University Press, 2008), pp. 56-70.

79. Gumilev, Ritmy Evrazii: epokhi i tsivilizatsii (Moscow: Ekopros, 1993), p. $3 \mathrm{I}$ (I quote here Mischa Gabowitsch's translation from Laruelle, Russian Eurasianism, p. 73).

8o. See Zweerde, Soviet Historiography of Philosophy, especially pp. 26-31; see also Nikolai Plotnikov, 'Sovetskaia filosofiia: institut i funktsiia' in Mikhail Ryklin 
et al. (eds.), Uskol'zaiushchii kontekst: russkaia filosofia v postsovetskikh usloviiakh (Moscow: Ad Marginem, 2002), pp. 287-302.

8I. See Iegoshua Iakhot, Podavlenie filosofii v SSSR (20-30 gody) (New York: Chalidze Publications, I98I), where the reader will find more factual information about the canonisation of Marxism-Leninism, including a discussion of the important Party resolution of I93I (about the journal Under the Banner of Marxism) and the infamous Short Course (1938).

82. See Nethercott's account in her essay, 'Philosophieren unter Stalin und unter Nikolaj I' in Klaus-Dieter Eichler and Ulrich Johannes Schneider (eds.), Russische Philosophie im 20. Jahrhundert (Leipziger Universitätsverlag, 1996), pp. 23-34, here p. 30.

83. Boris Porshnev, $O$ nachale chelovecheskoi istorii: problemy paleopsikhologii (Moscow: Mysl', 1974); this abridged edition was followed by a fuller but textologically not entirely reliable edition (St Petersburg: FERI-V, 2006). References here are to the most recent, unabridged and textologically more rigorous edition prepared by Oleg Vite (St Petersburg: Aleteia, 2007).

84. See Z. A. Chekantseva, 'Retseptsiia tvorchestva B. F. Porshneva vo Frantsii i v Sovetskom Soiuze' in Frantsuzskii ezhegodnik 2007 (Moscow: LKI, 2008), pp. 12-26, here pp. I5-17. From the narrower perspective of the guild, Aron Gurevich recognised Porshnev's enormous talent and compelling interdisciplinary breadth but thought his ideas spurious and untested by scrupulous research (A. Gurevich, Istoriia istorika (Moscow: ROSSPEN, 2004), pp. 25-8). Gurevich, who had attended Porshnev's seminars on historical psychology, refused to admit that Porshnev's 1966 book Sotsial'naia psikhologiia $i$ istoriia was, by Soviet standards, a pioneering work which preceded by several years his own work on historical psychology (see I. S. Filippov, 'B. F. Porshnev i politicheskaia ekonomiia feodalizma' in Frantsuzskii ezhegodnik 2007 (Moscow: LKI, 2008), pp. 87-I29, here p. I27). It was in Sotsial'naia psikhologiia $i$ istoriia that Porshnev praised Foucault for the first time, calling his Folie et déraison 'an outstanding work' (see Porshnev, Sotsial'naia psikhologiia i istoriia (Moscow: Nauka, 1966), p. 8, n. 7); Porshnev also refers to Foucault's book in $O$ nachale chelovecheskoi istorii (Porshnev, $O$ nachale, p. 395).

85. See Porshnev, $O$ nachale, p. II. In an unpublished piece, Porshnev dates the idea of the trilogy back to 1924 (see Oleg Vite, "Ia - schastlivyi chelovek". Kniga "O nachale chelovecheskoi istorii" i ee mesto v tvorcheskoi biografii B. F. Porshneva' in Porshnev, $O$ nachale, pp. 576-706, here p. 577).

86. See Porshnev, $O$ nachale, pp. 4I-2, 442. (Porshnev's praise of Marr is even stronger in an earlier article outlining the methodological foundations of the book: B. F. Porshnev, 'O nachale chelovecheskoi istorii' in Filosofskie problemy istoricheskoi nauki, ed. A. V. Gulyga and Iu. A. Levada (Moscow: Nauka, 1969), pp. 80-II2, here p. 97.) After Marr's dethronement in 1950, Porshnev's opponents sought to uncover in his work vestiges of Marr's by 
then deplorable 'new teaching'. In the mid-r96os, Porshnev wrote an article on Marr's centenary which remained unpublished (see Vite, "'Ia - schastlivyi chelovek"', p. 585).

87. See Porshnev, 'Kontrsuggestiia i istoriia' in Porshnev and L. I. Antsyferova (eds.), Istoriia i psikhologiia (Moscow: Nauka, I97I), pp. 7-35.

88. Ibid., p. 25 . 